\title{
The Blueprints of Definition in Technical Dictionary
}

\author{
Fitri Amilia \\ Pendidikan Bahasa dan Sastra \\ UniversitasNegeri Surabaya \\ Surabaya, Indonesia \\ fitriamilia@mhs.unesa.ac.id
}

\author{
Kisyani Laksono \\ Pendidikan Bahasa dan Sastra \\ UniversitasNegeri Surabaya \\ Surabaya, Indonesia \\ kisyani@unesa.ac.id
}

\author{
Budinuryanta Yohanes \\ Pendidikan Bahasa dan Sastra \\ UniversitasNegeri Surabaya \\ Surabaya, Indonesia \\ budinuryanta@unesa.ac.id
}

\begin{abstract}
Definition which refers to the term concept with different formation of the form of specific words in a dictionary has been the reason of the study. Collected data were in the form of definian taken from document record, identification and classification of the norms found in the dictionaries. The data collection technique was documentation done through note taking, identification, and classification of the definiandum formats. The data analysis was content analysis, similarities and distributions of the definian. The result of the study shows patterns of genus definition and differentia, synonymous, antonymous, negation, and broad and narrow, collocations, dual and multi, circular, context-bounded and context-unbounded, and zero definition. They show the level of information, clearness, and assurance of a concept. Contextual and non-contextual features were found in definition. Contextual refers to the meaning related to the field of study whereas non-contextual means the other way around. In the technical dictionary, the definition is provided in the form of contextual features to distinguish the technical meaning from the common one. The findings show that pragmatic an important reference in the conception of definian in technical dictionary as well as semantics called as Pragmasemantics.
\end{abstract}

Keywords: conception, contextual features, pragmasemantic.

\section{INTRODUCTION}

Definition pattern or blueprint refers to the conception of lemmaina technical dictionary. The conception follows the rules based on a certain dictionary; in which a language dictionary will be different from a learner's dictionary. Observations have revealed that there are variations in definition pattern; namely circular, synonymous, broad and narrow meanings, contextual or non contextual meaning. Based on the evidence, conceptions of definition is categorized into two called as informative and non-informative definition. For those reasons, further classification is required for this will be the basis of any improvement in the development of the technical dictionary in Indonesia and demands for norms or regulations on how to arrange lemma based on the dictionary category.
Numbers of norms are considered in the conception of lemma. First, based on the argument of Lanur [1], Sudibya [2] and Mundiri [3] it is the semantic consideration which rules the features to include or cover in the concept. Those features are the term concepts which will differ the meaning of a term when it is used in different context. These must be shortly and clearly written. This norm shows the importance of semantic in defining lemma in a dictionary, and Ogden and Richards argue that this will be completed through understanding the semantic triangle [4].

Another important norm is called contextual norms. It is based on the distinctions of contexts in type and functions of terms in technical dictionary from the common one. In technical dictionary, the meanings are always arranged based on the contexts within the specific area of study. Therefore, the meaning of a lemma in technical dictionary must be based on the contextual features. Hence, it is demanded to have a distinctive norm of conceptions to make it more applicable and advantageous that different dictionaries have different purposes [5].

From its types, meanings in a technical dictionary are closely bound to the contexts of the area of study. Hence, contexts hold a crucial role in the conception. The contexts here refer to the meaning of the writers/authors and the readers/learners or users of the dictionary [6]. This differs technical dictionary from the common one.

Semantic and pragmatic norms will be an alternative in improving the technical dictionary. The combination of both disciplines, semantic and pragmatic, is called as pragmasemantic. The pragmasemantic conception in technical dictionary will strengthen the evidence that there are differences in meaning of lemma within different contexts of a certain area of study. Terms in a certain area of study has strict rules of context usage which is different from other area of study. Thus, the contexts in pragmatic preserve to be the norms in the conception of meaning.

Molinowski has once done the study of pragmasemantics, but it was only related to the use of language in a society which 
revealed the evidence that meanings are closely related to the contexts. He emphasized that the meaning of a word is tied to its contexts [7].

Based on the evidence mentioned previously; this article aims at revealing the roles of pragmasemantics in the conceptions of meaning of lemma in the technical dictionary. Exposing the contextual features will assist the users or learners to uncover the meaning and usage of lemma within the area of study. This is in line that the competencies of learners in understanding the meaning and usage of lemma will be evident through its conception [8].

\section{METHOD}

This study is a qualitative research done up to August 2017. The data displayed were authentic, real and natural in the form of definitions found in the dictionary. The definitions were taken from nine technical dictionaries published in 1985 by Pusat Pengembangan dan Pembinaan Bahasa. Those dictionaries comprise Dictionary of Maritime [9], Dictionary of Fish Cultivation [10], Zoology Dictionary [11], Dictionary of Meteorology [12], Dictionary of Governance[13], Dictionary of Mineral Technology[14], Dictionary of Politics [15], and Dictionary of Commerce Administration [16]. The choice was due to the consideration that there has been no revision since those dictionaries were first published.

The data collection technique used was documentation. It was done through repeatedly and critically reading the dictionaries, marking the patterns, and classifying them. The data on conception were at least two from two different dictionaries to meet the validity of the research.

The selected data were then coded. Coding means to distinct different patterns found in the definitions. Similar data were then reduced. Content analysis, similarities and distributions of the definian were done in data analysis. Content analysis was started with classification of the definition patterns. Similarities were classified into three; referential, translational, and pragmatics. The data from similarities analysis were done to find characteristics of the features in the definition patterns. Meanwhile, the distribution of the definian was done through omissions and substitutions. Here, the features will be omitted or substituted with other features to uncover the roles of contexts within the conception. The data were displayed descriptively to find out the patterns of definition in the technical dictionaries. Findings on the patterns of definition will be the basis of conception in the technical dictionaries.

\section{RESULT}

Definition patterns refer to the conception of lemma. There are ten different patterns found in the technical dictionaries. Those patterns include genus definition and differentia, synonyms, negations, broad and narrow meanings, collocations, dual and multi definiandum, circular, noncontextual definition, and zero definition.

Genus definition and differentia (GD) is a conception pattern which gives primary features and its distinctive ones. The primary features mean to be the meaning of the lemma; this can be the hypermin, type, and species [17] and [18]. The conception pattern of GD can be done through networking procedure [19]. Meanwhile, the contextual features in GD are seen in the differentia features. It is found out that GD is filled with a concept which is categorized as a context. This context refers to SPEAKING by Hymes in which the contextual differentia shows the role of pragmatic within its conception. This proves that pragmasemantics has been in the conceptions of lemma in the technical dictionaries. Below is the example of pattern in GD.

1) Mahkamah militer luar biasa badan peradilan yang diserahitugas untuk memeriksa dan memutus dalam tingkat pertama dan terakhir perkara-perkara khusus yang ditentukan oleh Presiden RI (DGd, KTN)

Verhaar suggests that synonymous definition refers to the conception pattern which provides synonymous word of the given term [4]. This definition has a weakness that is always appear to be having different concept within the given synonymous word. It is based on the statement that synonymous words are words which have almost or nearly similar in meaning, not exactly similar. Synonymous in the synonymous definition also includes context related to the area of study. Here is the example

\section{(2) Politusahlinegara (DSi, KP)}

Negation definition refers to the conception pattern which applied the word which means "no" at the beginning of the given meaning. It is believed to be in contrast with the norms of definition conception [3].

\section{(3) absolut Tidak terbatas (Dn, KTN)}

Narrow definition refers to the conception pattern which mentions primary features without any distinctive features. This type of definition is visible from its length of words used in defining the term.

\section{(4) jukung jenisperahu (Dse, KK)}

Data (4) did not provide difference in lemma (4) from other lemma within similar classification.

Broad definition refers to the conception pattern which reveals the whole features of a lemma. This definition is very detailed, as given in a book. The indicator of broad definition can be seen from the completeness of the explanation, by giving formula, examples and detailed explanation from different experts. The length of words for this type of definition can reach 250 words.

Collocation definition refers to the conception pattern which provides words that shows its connection to the concept of location, bond, and resemblance. This definition, however, has not mentioned or given any clear features of a lemma. Yet, this definition usually provides contextual features.

Dual or multi-definition is conception pattern which provides more than one full patterns of definition; it is usually signed with numbers. It is found to be two to six concepts to explain the meaning of a lemma. This pattern is inappropriate with the rules or norms of defining meanings in the technical dictionary as a learner's dictionary. We can find contextbounded and context-unbounded definitions within this type of definition. 
Circular definition means a conception pattern which rewrites a word or more. It is evidence that there are abundant found in the technical dictionaries. And this conception has been against the rules of definition conception [3] and [1].

Contextual definition is defined as a conception which consists of features inappropriate with the contexts in a dictionary. This type of definition is not suitable with the category of dictionary, which is a learner's dictionary of a certain area of study. This type of definition is also considered as mistaken or incorrect pattern for every lemma is bound to its context.

Zero definition refers to inexistence or zero in features in its definition. This type of definition has two categories; first is by providing acronyms of a lemma and another one is by not providing any concepts of definition at all. This pattern does not give any information about the lemma. And in this study, there were only very minor evidence found in technical dictionaries. It was probably due to the negligence of the writers.

\section{DISCUSSION}

\section{1) Consistency and Inconsistency in Conception}

From the findings of ten definition patterns, it can be concluded that there is no exact rules or patterns in defining a lemma. It is evidenced that the patterns of definition were somehow consistent and inconsistent to the type or category of dictionary. What is called to be the appropriate pattern of definition is one which provides the features of lemma. These features refer to the term concept which is bound to its context when used. Meanwhile, a concept called to be inappropriate when it does not stick to the rules or norms of definition. These have become the indicators that there have been no maps or routes in defining a lemma in technical dictionary in Indonesia. Remeyi has revealed a different result about consistency and inconsistency of a conception within a dictionary [20]. And this has become a responsibility for dictionary makers to revise it. One reputable and ideal dictionary can be used as reliable reference for its readers.

Composing one ideal and reputable dictionary demands a careful and thorough understanding about the process of conception of a dictionary. Dictionary makers must be fully aware of the semantic blueprints. Alan states that semantic blueprints are sets of language evidence which show features, attributes, and functions within denotatum and also interaction of it to other features that is associated with [21]. Within a conception of a lemma as a term, semantic blueprints also require the blueprints of contexts within pragmatics.

In addition, a conception of a lemma also requires a precise conception of it. For this reason, there are two ways to be done, i.e. introspection and observation [22]. Introspection is in line with Chompsky statement about language competency of the language users [4]. Meanwhile, observation means to show the roles of texts in a conception.

Referring to observation, every term relates to the contexts of the area of study. Pateda states that a term possesses a definite meaning in which it is restricted to the context of the area of study [4]. Due to its relatedness to its context of study area, therefore a conception will be related to the contextual meaning of the term. By doing so, there will be no definition patterns which is out of the context as this study has revealed.

Understanding the patterns of definition, type or classifications of dictionary, and the appropriate ways of conceptions, the conception within technical dictionaries will reveal its consistencies. A conception within a certain pattern must be appropriate with the type or category of the dictionary. Consistencies in a dictionary conception reflect how consistent a conception is.

\section{2) Features of Conception}

In a conception of technical dictionary, non linguistics contexts will be found more abundant compare to linguistics contexts. In technical dictionary, non-linguistics contexts cover dictionary makers and the dictionary users or readers, purpose of conception, and the use of the terms in the context of study area. Non-linguistics contexts are covered in pragmatics section [23].

Within ten definition patterns, the features can be categorized into two; contextual and non-contextual features. Contextual features refer to meanings within the contexts of an area of study. Meanwhile the non-contextual features refer to meanings out of the context of an area of study. This categorization is based on the findings of definition pattern which compiles both features based on the contexts of the area of study and out of the context of the area of study.

Contextual features are classified into two; high contextual features and low contextual features. The terms high and low were first introduced through a language activity or communication in a society by Hall [24]. In this study, high contextual means that the dictionary is able to give the correct information based on the area of study to its users or readers. Meanwhile, low contextual means that the dictionary cannot give quite clear information based on the area of study to its users or readers, so that the reader will not get a complete understanding of the term he learnt.

In high contextual meaning, features provide meaning which is tied to the subject of study. The features are in the forms of genus pattern and diferentia, synonyms, negations, broad and narrow meanings, and circulars. Meanwhile, in low contextual meanings, the features refer to the context within the area of study but are vague or unclear. This can be seen from the collocation patterns.

Non-contextual features do not refer to the meaning based on the area of study in the technical dictionary. Those features tend to refer to the meaning in general. These features appear within the patterns of dual and multi definiandum, definition which is out of context of study area and zero definition.

\section{3) Contextual Features through Pragmasemantics}

It is uncovered that the conceptions encompass features which refer to the context of its use. Apart from it, in the common dictionaries, the written concept of definition is not bound to a certain context. Technical dictionary is exceptional [25]. This type of dictionary is also called the learner's dictionary. Therefore, the dictionary registers and writes, define the particular terms based on its context within the area 
of study. Atkins dan Rundell state that definitions in a learner's dictionary tend to be more contextual [8]. This can be seen from the features of its conception. Thus, technical dictionary registers lemma in the form of particular terms, and applies different conceptions of definition from the common dictionary.

The conception found in the technical dictionary is in the form of naming the contextual features within its definitions. This is evidenced that pragmatics has its roles as Yule said it to be a discipline about contextual meaning [6]. Not to mention that semantics also possesses essential roles in the conception, especially of lexical semantics [4].

Nida states that each word has the potential of having more than one meaning [26]. Hence, the word is possible to be a common word or a term which has exceptional meaning. For this reason, a different kind of conception is required. It can be done by mating semantics and pragmatics into one in order to define a term or lemma. Nowadays, semantics and pragmatics are considered to be two different disciplines, but are often overlapping [27]. The features found in the technical dictionary have strengthened a theory that semantics and pragmatics hold a strong bounding in defining meaning.

The data show that the written features are definitions of terms using pragmasemantics conception. The pragmasemantics conception found in the technical dictionary proves that disciplines are inseparable; instead, they are bound to one another in terms of expanding the discipline.

Features within the technical dictionary refer to the contextual meaning of the lemma. These features are named as contextual features. The contextual features in the technical dictionary have become the distinctive features of this type of dictionary from the common one. These features can be the genus or the diferentia (distinctive features). However, most of the data show that they tend to be the deferentia rather than the genus. This assures that pragmatic has its roles in the conception of the technical dictionary. Hence, it has become the basis of proposing the theory of pragmasemantics in the conceptions of a technical dictionary.

In addition, the proposal is also supported by the argument of Lewandowski and Hannapel/Wellenk [28] which state that in understanding a meaning, two ways are proposed; through lexical and contextual meaning. This is based on the purpose of writing the technical dictionary as well [29].

The explanation shows that pragmasemantics can be applied in the conception of technical dictionary. This can be done by including the contextual features in the definition of a lemma. The application of pragmasemantics here is due to the needs of the dictionary users or readers to uncover the meaning of terms or lemma in accordance to its contexts within the area of study.

\section{CONCLUSION}

The understanding of the dictionary makers in conception of lemma in the technical dictionary can be seen from the way they pattern the definition of the lemma itself. Composing an ideal technical dictionary demands full understanding of the makers about the contextual features of the lemma. And this can be done by applying pragmasemantics theory in the conception of lemma or terms in the dictionary.

\section{REFERENCES}

[1] O. O. Lanur, Logika, selayang pandang, Yogyakarta: Kanisus, 2007.

[2] D. W. F. Sudibya, Logika, Jakarta: Indeks, 2011.

[3] Mundiri, Logika, Jakarta: Raja Brafindo Persada, 2012.

[4] M. Pateda, Semantik Leksikal, Jakarta: Rineka Cipta, 2010.

[5] B. Steven, A handbook of lexicography: the theory and pratice od dictionary making, Cambridge: Cambridge university press, 2009.

[6] G. Yule, Pragmatik, Yogyakarta: Pustaka Pelajar, 2006.

[7] G. Senft, "Bronislaw Molinowski and linguistic pragmatic," dalam Lodz paper in pragmatic, Frankfurt, 2007, pp. 79-96.

[8] S. Atkins dan M. Rundell, The oxford guide to practical exicography, Oxford: Oxford University Press, 2008.

[9] Sogiono, P. Andrianto, Sukotjo, M. Wartono dan Asianto, Kamus Istilah Perkapalan, Jakarta: Puat Pembinaan dan Pengembangan Bahasa, 1985.

[10] K. Sumantadinata, E. Haris, D. Dana, S. L. Angka dan I. S. Mokoginto, Kamus Istilah Budi Daya Ikan, Jakarta: Pusat Pembinaan dan Pengembangan Bahasa, 1985.

[11] S. Sastrohadinoto, N. Sugirl, S. Somadikarta, H. D. Soesitiadi dan D. Sastradipradja, Kamus Istilah Zoologi, Jakarta: Pusat Pengembangan dan Pembinaan Bahasa, 1985.

[12] S. Wirjohamidjojo, R. Susanto, Sudjono, Sujitno dan Suhartono, Kamus Istilah Meteorologi, Jakarta: Pusat Pengembangan dan Pembinaan Bahasa, 1985.

[13] R. Awanwinata, B. Manan, K. Magnar, P. Ermaya dan R. S. M, Kamus Istilah Tata Negara, Jakarta: Pusat Pengembangan dan Pembinaan Bahasa, 1985.

[14] R. B. Soetjipto, D. Sumardi, Sulistijo, A. Sudarsono dan B. Sugeng, KamusIstilah Teknologi Mineral, Jakarta: Pusat Pengembangan dan Pembinaan Bahasa, 1985.

[15] J. Muhaimin, A. Rais, Sugiono, I. Hallina dan U. Salam, Kamus Istilah Politik, Jakarta: Pusat Pengembangan dan Pembinaan Bahasa, 1985.

[16] R. Ramli, T. T. Sian, H. Walandouw, S. Nurmantu dan A. Kasim, Kamus Istilah Administrasi Niaga, Jakarta: Pusat Pengembangan dan Pembinaan Bahasa, 1985.

[17] W. Poespoprodjo, Logika Scientifika, Pengantar Dialektika dan Ilmu, Bandung: Pustaka Grafika, 1999.

[18] L. Carrol, Simbolic Logic, New York: Dover Publications, Inc, 1955.

[19] H. Clark dan E. Clark, Psychology and Language: An Introduction to Psycholinguistics, San Diego: Harcourt Brace Jovanovich Publishers, 1977.

[20] D. Remenyi, A dictionary or research concepts and issues, England: Academic Publishing International, 2014.

[21] K. Allan, Natural Language Semantics, Oxford: Blackwell Publisher Ltd, 2001.

[22] A. Budiwiyanto, "badanbahasa," 2016. [Online]. Available: http://badanbahasa.kemdikbud.go.id/lamanbahasa/artikel/1580. [Diakses 2 Januari 2016].

[23] G. Leech, Prinsip-Prinsip Pragmatik, Jakarta: Universitas Indonesia, 1993.

[24] J. Nurkamto, "Berbahasa dalam budaya konteks rendah dan budaya konteks tinggi," Linguistik Indonesia, pp. 205 - 217, 2001.

[25] M. Iqbal, “thesis binus," 2011. [Online]. Available: 
http://thesis.binus.ac.id/doc/Bab2/2011-2-00206-ds\%20bab\%202.pdf.. [Diakses 20 Juli 2017].

[26] B. Y. Pelawi, "Aspek Semantik dan Pragmatik dalam Penerjemahan," Lingua Cultura, pp. 146-151, 2009.

[27] F. Recanati, "Pramatics and Semantics," dalam Handbooks of Pragmatics, United Kindom, Blackwell, 2006, pp. 442 - 462.

[28] L. Armelia, "Pemaknaan kontekstual ungkapan serapah bahasa jerman di kalangan remaja dalam novel "Und Wenn Schon," Universitas Indonesia, Jakarta, 2012.

[29] T. Setiawan, "Analisis Struktur Kamus Monolingual Bahasa Indonesia," Jurnal Litera, pp. 179 - 192, 2009. 